\title{
Teaching NeuroImages: Prosopagnosia heralding anti-NMDA receptor encephalitis
}

Grayson Beecher, MD, Amanda Nicole Wagner, MD, Jonathan Abele, MD, and Penelope Smyth, MD Neurology ${ }^{\circledR}$ 2018;90:e2012-e2013. doi:10.1212/WNL.0000000000005611
Correspondence

Dr. Smyth

smyth@ualberta.ca

Figure Neuroimaging findings in anti-NMDA receptor encephalitis presenting with prosopagnosia

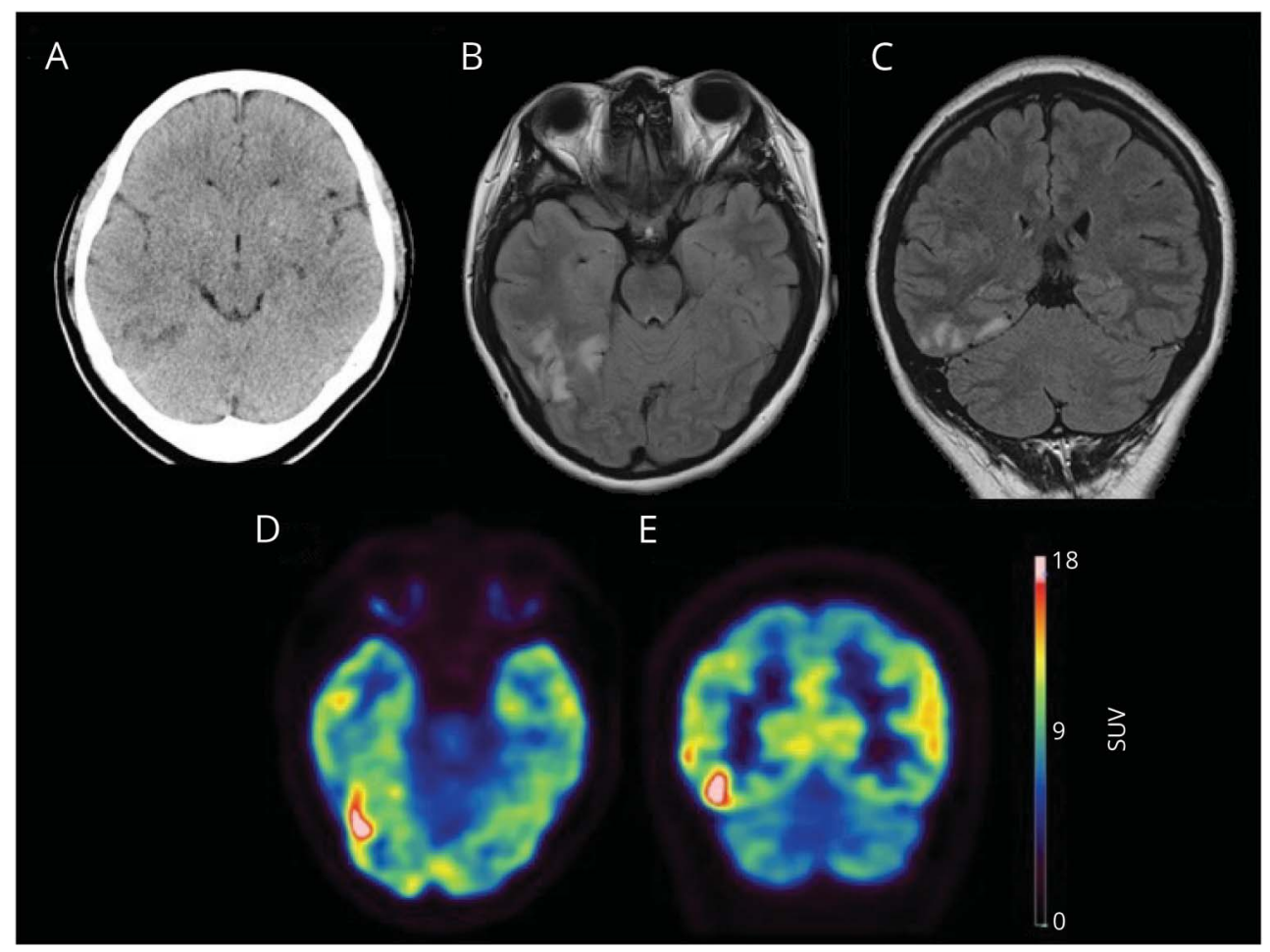

(A) CT head reveals right posterior temporal hypodensity. (B) Axial and (C) coronal T2 fluid-attenuated inversion recovery MRI demonstrate high signal in right posterior temporal lobe and fusiform gyrus. (D) Axial and (E) coronal FDG-PET/ CT images demonstrate right posterior-inferior temporal hypermetabolism (standardized uptake value $0-18$, CIMSNeuro scale, Oasis, Segami Corporation, Columbia, MD).
A 23-year-old right-hand-dominant woman presented with 3 weeks of progressive difficulty recognizing faces, including her own, subsequently developing psychosis. Noncontrast CT head and MRI brain with contrast revealed a nonenhancing lesion of the right posterior temporal lobe and fusiform gyrus, with corresponding hypermetabolism on FDG-PET/CT brain (figure). EEG demonstrated right posterior temporal slowing. CSF and serum anti-NMDA receptor (NMDAR) antibodies were positive, with CT abdomen/ pelvis revealing ovarian teratoma. Teratoma removal, plasmapheresis, and 1 cycle of rituximab yielded symptom resolution over 1 month. Anti-NMDAR encephalitis rarely presents with prosopagnosia, ${ }^{1}$ and in this case, is likely secondary to right fusiform gyrus dysfunction. ${ }^{2}$

\section{Author contributions}

Grayson Beecher performed the patient's clinical assessment, wrote the manuscript, and created the figure. Amanda Nicole Wagner assisted in writing the manuscript and figure legend.

\section{MORE ONLINE}

\section{$\rightarrow$ Teaching slides}

links.lww.com/WNL/A486

From the Department of Medicine (Neurology) (G.B., A.N.W., P.S.) and Department of Radiology \& Diagnostic Imaging (J.A.), University of Alberta, Edmonton, Canada. Go to Neurology.org/N for full disclosures. Funding information and disclosures deemed relevant by the authors, if any, are provided at the end of the article. 
Dr. Jonathan Abele reported the FDG-PET/CT imaging findings, provided the figure images, and edited the manuscript. Penelope Smyth assisted in the patient's clinical assessment and performed a critical revision of the manuscript for intellectual content.

\section{Study funding}

No targeted funding reported.

\section{Disclosure}

The authors report no disclosures relevant to the manuscript. Go to Neurology.org/N for full disclosures.

\section{References}

1. Sawamura H, Yamamoto T, Ohtomo R, Bannai T, Wakakura M, Tsuji S. Anti-NMDA receptor encephalitis associated with transient cerebral dyschromatopsia, prosopagnosia, and lack of stereopsis. J Neuroophthalmol 2014;34:144-148.

2. Barton JJ. Disorders of higher visual processing. Handb Clin Neurol 2011;102: $223-261$. 


\section{Neurology}

Teaching NeuroImages: Prosopagnosia heralding anti-NMDA receptor encephalitis

Grayson Beecher, Amanda Nicole Wagner, Jonathan Abele, et al.

Neurology 2018;90;e2012-e2013

DOI 10.1212/WNL.0000000000005611

This information is current as of May 28, 2018

Updated Information \&

Services

References

Subspecialty Collections

Permissions \& Licensing

Reprints including high resolution figures, can be found at: http://n.neurology.org/content/90/22/e2012.full

This article cites 2 articles, 0 of which you can access for free at: http://n.neurology.org/content/90/22/e2012.full\#ref-list-1

This article, along with others on similar topics, appears in the following collection(s):

MRI

http://n.neurology.org/cgi/collection/mri

PET

http://n.neurology.org/cgi/collection/pet

Visual processing

http://n.neurology.org/cgi/collection/visual_processing

Information about reproducing this article in parts (figures,tables) or in its entirety can be found online at:

http://www.neurology.org/about/about_the_journal\#permissions

Information about ordering reprints can be found online:

http://n.neurology.org/subscribers/advertise

Neurology ${ }^{\circledR}$ is the official journal of the American Academy of Neurology. Published continuously since 1951, it is now a weekly with 48 issues per year. Copyright @ 2018 American Academy of Neurology. All rights reserved. Print ISSN: 0028-3878. Online ISSN: 1526-632X.

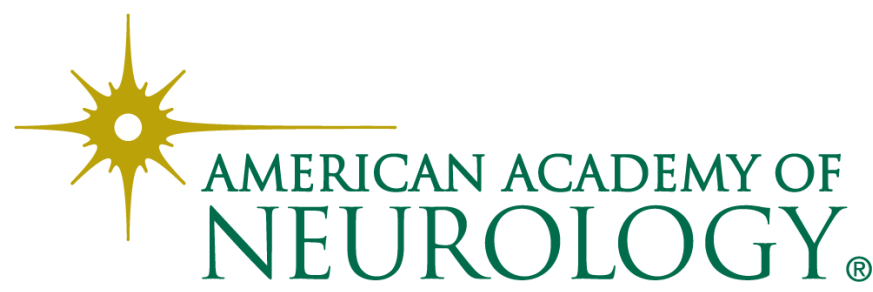

